\title{
What It Means To Be a Teacher in a Higher Education Context Today - With Emphasis on South Africa
}

\author{
Kevin A. Johnston \\ University of Cape Town, Cape Town, South Africa
}

kevin.Johnston@uct.ac.za;

\begin{abstract}
The purpose of this paper is to highlight what it means to be a teacher in a higher education context, with some emphasis on South Africa. The teaching component was examined from several aspects. The approach taken is that of a provocative essay rather than of a formal academic paper. It is argued that many academics should see themselves as both teachers and researchers, and it is shown what it means to be a teacher in a higher educational context today. The paper aims to contribute to the field of IS research by sensitising academics to possible different approaches to teaching.
\end{abstract}

Keywords: teaching approaches, higher education, research

\section{Introduction}

There is a tendency amongst some academics and many administrators to think that research out put is the most critical component of academic work, perhaps because it is so easy to quantify. Universities and academics are rated and measured on research output, and research output brings prestige and money to an institution. Teaching however is less easy to measure, not as prestigious and is not as recognized as research in many higher educational institutions today. This results in many academics not taking the teaching aspect as seriously as they take the research aspect of their jobs, after all they are recognized and rewarded for research. In South African higher educational institutions the emphasis is clearly on research output today. The majority of students however, particularly undergraduates (and particularly in developing countries such as South Africa) would like good teachers in order to enhance their understanding and learning. The question, 'what does it mean to be a teacher in a higher education context today?' was examined from several aspects, what is a teacher free to do, what is the role of a teacher, what teachers teach, and how teachers teach.

Material published as part of this publication, either on-line or in print, is copyrighted by the Informing Science Institute. Permission to make digital or paper copy of part or all of these works for personal or classroom use is granted without fee provided that the copies are not made or distributed for profit or commercial advantage AND that copies 1) bear this notice in full and 2) give the full citation on the first page. It is permissible to abstract these works so long as credit is given. To copy in all other cases or to republish or to post on a server or to redistribute to lists requires specific permission and payment of a fee. Contact 0HPublisher@InformingScience.org to request redistribution permission.

\section{Academic Freedom}

Academics should see themselves as both teachers and researchers. An essential aspect of being an academic is academic freedom. Academic freedom is a relevant and persisting problem around the world, although it has no commonly accepted definition. There have been many debates and papers published on 
academic freedom. International papers include (Collins, 2009; Crabtree, 2002; Ivie, 2005) and South African papers include (Bentley, Habib, \& Morrow, 2006; du Toit, 2000; Haffajee, 2005; Southall \& Cobbing, 2001). Organisations such as the Network for Education and Academic Rights (NEAR), Scholars at Risk, Council for Assisting Refugee Academics and the Scholar Rescue Fund exist to raise the issue of academic freedom and assist academics under threat. Academic freedom continues to be discussed at conferences such as the Unesco World Conference on Higher Education in Paris from 5-8 July 2009. In December 2008, Professor Nithaya Chetty resigned from the University of KwaZulu-Natal South Africa despite appeals from academics and organisations around the world (Travis, 2008).

The concept of academic freedom dates back to classical Greek times when Plato established the Academy which was based on a duty to seek and speak the truth (Crabtree, 2002), however this did not involve institutions, administration and processes. The first universities were founded in the Medieval Period as quasi-ecclesiastical institutions with an almost sacred duty to search for and teach the truth (Crabtree, 2002; Russell, 1993). The concept of academic freedom during the middle ages was thus deontological (duty and obligation), and as a result, both political and religious powers granted medieval universities considerable autonomy in their internal affairs (Crabtree, 2002). In Europe in the nineteenth century, the motivation for academic freedom in universities particularly those in Germany was teleological (purpose served), and there to serve and develop the state (Crabtree, 2002; Bentley, Habib, \& Morrow, 2006). These divergent views (deontological and teleological) of the purpose of academic freedom have caused much debate in South Africa (Bentley, Habib, \& Morrow, 2006). The meaning of words and concepts changes over time, and the word 'freedom' has many meanings which range from personal liberty from slavery and detention, to freedom of movement and assembly, freedom from want, freedom of choice, freedom of access, and freedom to take certain actions without control or interference. Like freedom, the term academic freedom is not static, and as it dates back to medieval times its meaning has changed over time (Russell, 1993).

Up until the early 19th century, academic freedom broadly meant the freedom to teach and the freedom to learn without external control or interference (Altbach, 2001). This view was shared in South Africa in the middle of the 20th century. Davie the Vice-Chancellor of the University of Cape Town from 1948 to 1955 defined academic freedom as the freedom and right of a university to decide "who shall teach, what we teach, how we teach, and whom we teach" (Bentley, Habib, \& Morrow, 2006, p. 32; du Toit, 2000). Interestingly, no mention was made of learning, research or administration in the Davie definition, only teaching, yet as recently as 2000 Higgins asserted that this definition was correct (Higgins, 2000), and it is still widely used and quoted in South Africa.

The British definition of academic freedom in the amendment to the Education Bill of 1988 gives academics "the freedom within the law to question and test received wisdom, and to put forward new ideas and controversial or unpopular opinions without placing themselves in jeopardy of losing their jobs or privileges they may have at their institutions" (Russell, 1993, pp. 1-2). No mention is made of teaching, research or administration and it has the strong caveat "within the law" which could seriously undermine any freedoms.

A contemporary meaning (rather than a definition) of academic freedom is of a constantly changing "relationship between faculty and their discipline, students, university administrators, communities, and governmental bodies" (Aby \& Kuhn, 2000, p. vii). This meaning covers a wide range of threats to academic freedom from administration to government. Administrators and Governments could for example change various aspects such as funding models (Bentley, Habib, \& Morrow, 2006), entrance criteria, promotional criteria for a particular faculty or institution which fails to comply with a set agenda. The US government tightened controls over access to information, restricted the expression of ideas and the recruiting of international students and 
scholars, and constrained government funding in response to the September 11 attacks in 2001 (Toma, 2006). External pressures from governments such as constraining funding, and pressures from advocacy groups can also encourage self-censorship in an institution, which further erodes academic freedom (Toma, 2006).

Academic freedom provides academics opportunities for both innovation and for complacency. As Davie's definition of academic freedom is pertinent to teaching, it will be used to examine what it means to be a teacher today. Davie defined academic freedom as freedom from external interference in:

a) who shall teach,

b) what we teach (content),

c) how we teach (methods), and

d) whom we teach (Bentley, Habib, \& Morrow, 2006).

Teaching in academia today is however conditioned or controlled by several forces:

e) control over entry into occupations by credentials and research record,

f) control over the course content by teachers, administrators and members of the discipline (Martin, 1998),

g) control over course process (method) by facilities available,

h) control over admission of students by the institution (and Government), and

i) control over promotion through research (not usually teaching) by the institution.

A teacher in a higher educational institution today may have influence over (e) who enters academia (f) course content, (g) course process and (h) admission of students, but several other forces exert control. However these other forces do not determine the details of content, teaching method or promotion. There are opportunities to promote alternative content (questions, truth, survival, passion) and methods (self-paced, student choice of topics, relevance, inquiry, ICT) as academic freedom gives individual teachers opportunities to do things differently in the privacy of their own classrooms. There are also opportunities to do research (critical not safe research) on all five forces, plus of course opportunities to do research on discipline related issues as well as in broader societal areas as is discussed later. The bottom line however is that academics today do not have freedom from external interference in any of the four points raised by Davie, but have some influence.

\section{Teacher's Role}

A teacher's role is to pass on knowledge, to develop skills and develop wisdom, passion and commitment in students. Kierkegaard claimed that to have a meaningful life the learner must pass through the aesthetic, the ethical and the religious spheres of existence, and a good educator facilitates this (Dreyfus, 1999). Each of these spheres will be briefly examined. Today virtually anyone who is not severely handicapped can learn anything, anywhere, anytime using the internet. There is so much information available on so many subjects, but what is relevant and significant is not easy to discover, and this is one role of a teacher.

The aesthetic sphere is a commitment to the enjoyment of sheer information (Dreyfus, 1999). Today's student can visit as many sites as he/she likes and keep up to date on various aspects and issues. But there can be no thrill, no excitement as there is no risk, and no real involvement. Lacking some means of determining what is relevant, significant and applicable; the whole thing becomes unappealing and boring. A teacher can help a student discern the relevant from irrelevant, the significant from the insignificant, and the applicable from the inapplicable (Dreyfus, 1999). But and it's a big but, relevant and significant for whom? 
The ethical sphere consists of turning information into knowledge (Dreyfus, 1999). This can only happen if the information sought should be for serious purposes. This happens if a person commits to some point of view, and chooses something interesting to learn about, something that has a sense of relevance to that person. Information can only be turned into knowledge if a person is committed and involved. Being committed and involved requires taking certain risks. If there is no risk and no consequences, the decisions as to what information to seek are uninformed and meaningless. Unless there is engagement, a consequence and a possibility of failure or success a learner will not develop the skill and competence to achieve mastery. A teacher should give a learner a serious purpose and extract a commitment to some perspective, make the learner take risks; make the outcome matter for the student (Dreyfus, 1999).

The religious sphere consists of making one unconditional commitment (Dreyfus, 1999). This is a strong commitment which seizes and consumes one's whole being. Love, politics, religion, music, art can seize one's whole being, and so define all one's other everyday commitments. Such unconditional commitments establish what is important, relevant, and serious to an individual. Choices are limited and the individual bases all choices on this commitment. Nelson Mandela's final sentences at the Opening of the Defense case in the Rivonia Trial Pretoria Supreme Court, 20 April 1964 are an excellent example of unconditional commitment. Mandela said, "I have cherished the ideal of a democratic and free society in which all persons live together in harmony and with equal opportunities. It is an ideal which I hope to live for and to achieve. But if needs be, it is an ideal for which I am prepared to die" (Mandela, 1995, p. 438). Such unconditional commitments are risky, Mandela's commitment cost him 27 years in prison. Less serious risks may include one's cause failing, one's lover walking away. But there is no way to have a meaningful life and to develop particular skills and wisdom without taking certain risks (Dreyfus, 1999). Teachers need to have strong identities, unconditional commitment, be ready to take risks and to pass on their passion and skill to their students. Teachers need to be near their students to get the students to strive for unconditional commitment to develop wisdom, passion and unconditional commitment. A test to see if a one has an unconditional commitment is to see 'if one has the incentive and courage to transfer what one had learned to the concrete situation in the real world' (Dreyfus, 1999, p. 19).

The French philosopher De Montaigne linked education and teaching with philosophy, and believed that teachers should attempt to get students to mould and form judgment and manners (Foglia, 2004). The core of education should be to develop a student's ability to use his/her judgment in every situation in everyday life. Priority should be given to the formation of judgment and character rather than memory and recall. What is important is the way we exercise our judgment, the way we search for truth rather than the finding of it. "The question is not who will hit the ring, but who will make the best runs at it." De Montaigne was emphatic that dialogue and questioning formed an important part of teaching, and referred to Socrates' method of continually asking questions to ensure conversations continued (Foglia, 2004). The role of the student is not to repeat what the teacher has said, but to confront the teacher's judgment with his or her own judgment (Foglia, 2004).

Teachers were challenged to ask themselves the following three questions daily: "What am I going to have my students do today? What is it good for? How do I know?" (Postman \& Weingartner, 1969).

Teachers in a higher educational institute need to ask themselves should my role as a teacher be:

- to stick to the same old content and methods, or promote alternative content and methods?

- to serve up tired old theories, or to launch unfettered inquiries into new exciting worlds?

- to pursue research to get promotion, or to do critical research without fear or favour? 
- to fling out theory and facts and set questions, or to embark on a never-ending quest for new questions and insights?

- to point students in a direction, or to give serious purpose and extract commitments?

- to hide their identities and commitments and shy away from taking risks, or to have strong identities, unconditional commitment, and be ready to take risks?

- to be distant from or near to students?

- to simply to pass on information and knowledge, or to develop skills, wisdom, passion and commitment?

\section{What We Teach Part 1 (The Content)}

The teacher has some discretion over the content taught. The teacher can often choose the material to be covered, the texts to be used, the examination questions and essay topics. With this freedom, considerable scope exists for changing the content. The course can focus on academic issues or on broad applications; it can sample a range of viewpoints or be very partisan.

Hamid's view of what we teach in South Africa was made clear in the following quotation. "Tertiary education is not taking the appropriate measures to match the curriculum with the market demands. Moreover, universities are implementing outdated modules and learning material, and their prehistoric approach is creating a huge unemployment gap. It is essential that the universities evolve their outdated and archaic methods and structures to support the future of technology within South Africa" (Franz-Kamissoko, 2009).

So why do some academics introduce critical content into their courses and others not? They could be concerned about social issues - such as poverty, AIDS or racism - and realise that the usual courses shortchange critical perspectives.

They could (and should) ask themselves what the purpose of education is?

- Is it to expand to the limit the individual's capacity and desire for self education, for seeking and finding meaning, truth and enjoyment in everything he or she does?

- Is it to increase the survival prospects of the group to which the individual belongs? (Johnston, 2003).

Similarly teachers particularly those in higher educational institutes should ask themselves:

- Am I teaching students to question, or to be questioned?

- Do I teach students discovery or what has been discovered?

- Do I teach students to seek truth even if it does not serve our cause?

- Do I teach students enjoyment and passion, or do I teach routine, fear and anxiety?

- Do I teach students to survive, to adapt to change, or do I teach them to conserve old ideas, concepts and attitudes?

If a teacher decides to add critical content, the most immediate threat and constraints arises from the teacher's colleagues. There is usually no problem if the colleagues approve and support the initiative. But if they oppose the initiative, their resistance is often so strong and intimidating that the teacher often backs down. A teacher can anticipate arguments such as the content is at variance with the prescribed syllabus, the content is not rigorous or relevant to the discipline, some students may object to the content, and the correct procedure to change content has not been followed (Martin, 1998). If the teacher persists the institution can start formal proceedings against the teacher or simply reallocate the course to another teacher.

A teacher's biggest challenge when changing course content is to make it a relatively permanent change. The only way in which to do this is to have support from some if not all of one's col- 
leagues, without this support the content will revert to the old content as soon as the teacher is replaced (Martin, 1998). A teacher needs the committed support of a significant group of colleagues in the department to succeed. The students may be a second source of opposition due to their school and social experiences which teach them not to question, but rather to listen and follow orders to get ahead (Martin, 1998).

\section{How We Teach (The Methods)}

The methods used to teach are less contentious and usually easier to change. Many of the teaching methods employed are controlled by the teacher, but when students are allowed to choose what and how they learn, they are more likely to develop critical perspectives.

There are numerous initiatives which can be used in teaching including:

- Self-paced learning. A syllabus can be set up in modules in which students study at their own pace. Assessment can be carried out as each module is completed (Martin, 1998).

- Student choice of topics. Students, as individuals or in groups, can be given the opportunity to choose topics for study or investigation, within the overall framework of the subject. The teacher can maintain overall control through veto power over topics and through assessments (Martin, 1998).

- Student participation in assessment. Peer assessment and self-assessment. One difficulty is that peer assessment may increase competitive pressures (Martin, 1998). A more general problem is that the standard of assessment is maintained.

- Student-oriented learning. Pair learning: each student listens to one other student describe their views on a particular issue (Blanton, 2002). No interruptions are allowed. The talking and listening roles are then reversed. This allows students to describe their ideas without the teacher hearing them, and with no interruptions from dominant students (Martin, 1998). The biggest problems are assessment and credentials.

- Student design of learning. Students are expected to design their own plan of study, either as individuals or in groups. Staff (or other students, or member of the community) act as advisers (Martin, 1998).

- Pursue relevance - what is worth knowing? What is it good for? When will we ever need this? How do I know? (Postman \& Weingartner, 1969).

- Inquiry method. Make sure that it becomes habit for students to question and challenge everything (Blanton, 2002). Force students to ask questions, by setting tutorials and examinations where they have to ask questions.

- Process not product is important. Don't become fixated on syllabi. Students learn best by doing, people learn to walk by walking. "We see what we understand rather than understand what we see" (Labinowicz, 1985).

Then there is the use of technology in teaching, this could include:

- using the internet to find information

- using learning management software to manage courses

- using learning management software to write exams,

- using social networking sites such as Facebook or Twitter to communicate and question,

- using laboratories as classrooms,

- using podcasting to get material to students.

Teachers who promote these types of alternatives are essentially connecting with the students rather than with disciplinary or administrative powers. Teachers who push for greater student participation in learning find that students learn more when they are involved in controlling their 
own learning. Opposition once again comes primarily from one's colleagues who prefer to maintain the status quo and prefer to maintain power (Martin, 1998).

\section{What We Teach Part 2 (The Research)}

Academic freedom is also supposed to allow academics to pursue their inquiries without fear or favour (Martin, 1998). Few academics however do any critical questioning research because of what is acceptable to journals and conferences, what is considered socially acceptable (Martin, 1998), and what is necessary to advance in the educational system. Information Systems (IS) research has been dominated by a positivist epistemological stance (theory of knowledge) probably due to the encouragement and endorsement of the top IS research journals (Sidorova, Evangelopoulos, \& Ramakrishnan, 2007). Of the IS papers published in major United States IS Journals between 1991 and $200189 \%$ had a positivist epistemology and 11\% had an interpretive epistemology, while of the papers published in European IS Journals $66 \%$ were positivistic and 34\% were interpretive (Becker \& Niehaves, 2007). This means no papers were published using a critical epistemological stance. With regard to what is socially acceptable, how many academics published papers on cruelty to animals in scientific experiments before the rise of the animal liberation movement (Martin, 1998)? How many papers are published simply to get ahead in the promotional race, the old 'publish or perish' dilemma and the content or impact is considered irrelevant? It has been stated that some research agendas are determined by governments or corporations who are prepared to pay for certain research, obviously a violation of academic freedom (Bentley, Habib, \& Morrow, 2006).

Academics should use their academic freedom to challenge and question all systems, including the higher educational systems in which they operate. Possible areas of critical research include:

- Analysis of the curricula and societal and market demands,

- Analysis of teaching methods and structures

- Analysis of inconsistencies and biases in higher educational and government policies,

- Evaluation of dangers to Universities from poverty, AIDs etc.

- Development of strategies for promoting the interests of minorities.

A teacher's research should be about what is important, relevant, and serious to that individual, preferably something they feel passionate about. A teacher should be committed to research and the research should contain some element of risk to the teacher. As stated previously teachers need to be ready to take risks and to pass on their passion and skill to their students. One risk is the danger of suppression by administrators or academics (Martin, 1998). The test used earlier to see if a teacher had unconditional commitment could also be used to check on the research one is pursuing, 'if one has the incentive and courage to transfer what one had learned to the concrete situation in the real world' (Dreyfus, 1999, p. 19). Would a teacher be prepared to refer to the research he/she has worked on in the classroom?

\section{Conclusion}

The author believes that to be a teacher in a Higher Education context today means continually asking oneself four questions:

1. Is the content one is teaching relevant?

2. Is one using the most appropriate methods to teach today?

3. Is one doing critical research in one's subject area?

4. Is one listening and engaging with the students? 
Each teacher should be challenged to ask themselves the question, "Why am I a teacher?" They then need to be challenged to give themselves an honest answer and to reflect on that answer.

\section{References}

Aby, S. H., \& Kuhn, J. C. (2000). Academic freedom: A guide to the literature. Westport: Greenwood.

Altbach, P. G. (2001). Academic freedom: International realities and challenges. Higher Education, 205219.

Becker, J., \& Niehaves, B. (2007). Epistemolgical perspectives on IS research: A framework for analysing and systematizing epistemological assumptions. Info Systems Journal, 17, 197-214.

Bentley, K., Habib, A., \& Morrow, S. (2006). Academic freedom, institutional autonomy and the corporatised university in contemporary South Africa. Pretoria: Council on Higher Education (CHE).

Blanton, P. (2002). All I need to know about teaching I learned from my students. The Physics Teacher, 557-558.

Collins, J. (2009). Interrogating the politics of post 911 academic freedom. College Literature, 142-152.

Crabtree, D. (2002). Academic freedom. Retrieved April 10, 2009, from McKenzie Study Centre, Gutenberg College: http://www.mckenziestudycenter.org/education/articles/acadfree.html

Dreyfus, H. L. (1999). Anonymity versus commitment: The dangers of education on the internet. Ethics and Information Technology, 15-21.

du Toit, A. (2000). From autonomy to accountability: Academic freedom under threat in South Africa. Social Dynamics, 76-133.

Foglia, M. (2004). Michel de Montaigne. Retrieved November 21, 2009, from Stanford Encyclopaedia of Philosophy: http://plato.stanford.edu/entries/montaigne/

Franz-Kamissoko, L. (2009, October 14). Shared investment. iWeek Magazine .

Haffajee, F. (2005, December 15). Intellectual freedom not for sale. Retrieved March 30, 2009, from Mail \& Guardian: http://www.mg.co.za/article/2005-12-15-intellectual-freedom-not-for-sale

Higgins, J. (2000). Academic freedom in the new South Africa. Boundary, 2, 97-119.

Ivie, R. L. (2005). A presumption of academic freedom. The Review of Education, Pedagogy, and Cultural Studies, 53-85.

Johnston, K. A. (2003). The answer is the question. Informing Science and IT Education Conference. Pori, Finland: InSITE.

Labinowicz, E. (1985). Learning from children. Menlo Park: Addison-Wesley.

Mandela, N. (1995). Long walk to freedom. London: Abacus.

Martin, B. (1998). Critical teaching and research. In B. Martin, Tied knowledge: Power in higher education. Wollongong: University of Wollongong.

Postman, N., \& Weingartner, C. (1969). Teaching as a subversive activity. Penguin Education.

Russell, C. (1993). Academic freedom. London: Routledge.

Sewchurran, K., \& Brown, I. (2009). Research as formulating perspectives to make sense of problematic situations. Unpublished paper.

Sidorova, A., Evangelopoulos, N., \& Ramakrishnan, T. (2007). Diversity in IS research: An exploratory study using latent semantics. ICIS 2007. Montreal: AIS.

Southall, R., \& Cobbing, J. (2001). From racial liberalism to corporate authoritarianism: The Shell affair and the assault on academic freedom in South Africa. Social Dynamics, 1-42. 
Toma, J. D. (2006). Review of academic freedom at the dawn of a new century: How terrorism, governments, and culture wars impact free speech. The Journal of Higher Education, 482-484.

Travis, J. (2008). University world news. Retrieved April 02, 2009, from UNESCO Academic Freedom: http://universityworldnews.com

\section{Biography}

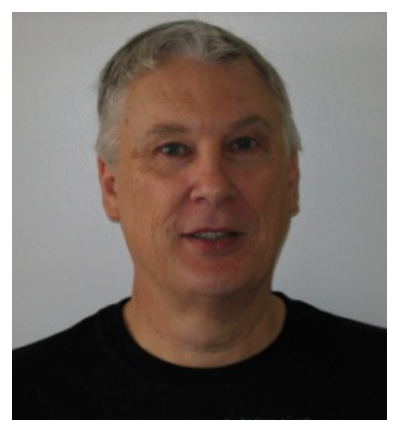

Kevin Johnston is currently an Associate Professor the Department of information Systems at the University of Cape Town (UCT), South Africa. He taught Mathematics \& Science at High Schools before working for 24 years in industry for companies such as WilsonRowntree, De Beers, Liberty Life, Lifegro (Legal \& General Volkskas) and BoE in South Africa and Botswana. Kevin joined UCT in 2001 as Senior Lecturer in the Department of Information Systems. His main areas of interest are ICT Management and Project Management. 